Hydrology and Earth System Sciences, 8(5), 959-972 (2004) C EGU

\title{
Strontium isotope geochemistry of alluvial groundwater: a tracer for groundwater resources characterisation
}

\author{
Philippe Négrel, Emmanuelle Petelet-Giraud and David Widory \\ BRGM, Avenue C. Guillemin, BP 6009, 45060 Orléans Cedex 02, France \\ Email for corresponding author : p.negrel@brgm.fr
}

\begin{abstract}
This study presents strontium isotope and major ion data of shallow groundwater and river water from the Ile du Chambon catchment, located on the Allier river in the Massif Central (France). There are large variations in the major-element contents in the surface- and groundwater. Plotting of $\mathrm{Na}$ vs. $\mathrm{Cl}$ contents and $\mathrm{Ca}, \mathrm{Mg}, \mathrm{NO}_{3}, \mathrm{~K}, \mathrm{SO}_{4}, \mathrm{HCO}_{3}, \mathrm{Sr}$ concentrations reflect water-rock interaction (carbonate dissolution for $\mathrm{Ca}, \mathrm{Mg}, \mathrm{HCO}_{3}$ and $\mathrm{Sr}$ because the bedrock contains marly limestones), agricultural input (farming and fertilising) and sewage effluents (for $\left.\mathrm{NO}_{3}, \mathrm{~K}, \mathrm{SO}_{4}\right)$, although some water samples are unpolluted. Sr contents and isotope ratios $\left({ }^{87} \mathrm{Sr} /{ }^{86} \mathrm{Sr}\right.$ vary from 0.70892 to 0.71180 along the hydrological cycle) in the groundwater agree with previous work on groundwater in alluvial aquifers in the Loire catchment. The data plot along three directions in a ${ }^{87} \mathrm{Sr} r{ }^{86} \mathrm{Sr} v s .1 / \mathrm{Sr}$ diagram as a result of mixing, involving at least three geochemical signatures-Allier river water, and two distinct signatures that might be related to different water-rock interactions in the catchment. Mixing proportions are calculated and discussed. The alluvial aquifer of the Ile du Chambon catchment is considered, within the Sr isotope systematic, in a larger scheme that includes several alluvial aquifers of the Loire Allier catchment.
\end{abstract}

Keywords: Loire river, major and trace elements, Sr isotopic ratio, alluvial aquifer, hydrology

\section{Introduction}

Interactions between groundwater and surface water are complex and depend on many factors including landform, geology, climate and the exploitation of local water resources (Adams et al., 2001). The hydrology and water quality of rivers are strongly controlled by exchanges of water and solutes with adjacent river banks and uplands (Sikdar et al., 2001; Ray et al., 2002). Ground- and surface water can be seen as linked components in a larger hydrological continuum that should be considered for sustainable development (Eikenberg et al., 2001; Négrel et al., 2003). The quality of groundwater, the main source of drinking water in most European countries, is increasingly threatened by anthropogenic activities (industrial processes, intensive agriculture, irrigation, tourism, etc.). Alluvial valleys are favoured for both industrial and agricultural activities and concentrated population (Guo and Wang, 2004). Riverbank aquifers constitute water reservoirs that are used not only as sources of drinking water for a large part of the European population but also supply water for irrigation and industrial processes. Most are unconfined and have porosity and hydraulic conductivity that allows efficient water movement. Due to these physical properties, many alluvial aquifers are vulnerable to pollution. Given the increasing demand for water, these resources are likely to be increasingly solicited in the future, and it is therefore necessary that they be protected from anthropogenic impacts and land degradation.

The aim of this study was to couple isotopic and chemical tracing to constraints and evaluate riverbank aquifer recharge and study hydraulic links with rivers and chemical transfer between surface and groundwater. Systematic variations in the isotopic composition of surface- and groundwater can result either from water-rock interactions or an input of pollutants that are chemically or isotopically different from the water (Petelet et al., 1998; Roy et al., 1999; Semhi et al., 2000; Ojiambo et al., 2003; Widory et al., 2004). They can be used to identify contributions from different sources and, under optimum conditions, to quantify the relative 
contributions from the various sources identified (Grosbois et al., 2000; Böhlke and Horan, 2000; Douglas et al., 2002; Négrel and Pauwels, 2004).

\section{Site description, hydrogeological context}

The Ile du Chambon catchment (100 ha) is located in the Allier valley in the centre of France, near Vichy (Fig. 1). The Allier River (410 km long) is the main tributary of the Loire (1010 km long) and its river basin has a total surface area of $117800 \mathrm{~km}^{2}$. The river originates in the Massif Central and joins the Loire near Nevers. It flows through the Limagne graben along almost the whole stretch and meanders to the city of Moulins (Giot et al., 1976; Dadet et al., 1979, 1980). Large amounts of sand and gravel are transported during floods and the morphology of the river changes significantly from year to year. In the upper part of the basin, which represents $46 \%$ of the basin's total surface area, the Loire and Allier rivers flow roughly south to north, draining old plutonic and volcanic rocks (Négrel et al., 1997; Grosbois et al., 2000, 2001).

In the Limagne region, the Allier drains Eocene to Miocene sedimentary formations, including sequences of clastic and carbonate sediments. The groundwater in the riverbank alluvial aquifer in the Ile du Chambon catchment drains Quaternary Allier river alluvial deposits (around $10 \mathrm{~m}$ thick; Dadet et al., 1979) encompassing silicate components of granitic-gneissic and basaltic origin from the Massif Central, i.e. made up for the most part of clay and sand derived from crystalline, metamorphic and volcanic rocks. These alluvial deposits overlie 'Bourbonnais' sandy-clayey deposits (Dadet et al., 1979; Delance et al., 1988) made up mainly of clay, sand and gravel from crystalline, metamorphic and volcanic rocks from the Massif Central and lacustrine carbonaceous deposits (Oligocene; Dadet et al., 1979). The Oligocene deposits were mainly supplied by lake sedimentation owing to certain marine incursions evidenced by combining fossil and fauna associations and isotopic tracing (Bodergat et al., 1999; Briot et al., 2001).

Average annual rainfall (P) in the area is $780 \mathrm{~mm} \mathrm{yr}^{-1}$ and a true evaporation rate $(\mathrm{E})$ is about $590 \mathrm{~mm} \mathrm{yr}^{-1}$. The calculated concentration factor $(\mathrm{P} / \mathrm{P}-\mathrm{E})$ is around 4 (BRGM, 1983; Dadet et al., 1979). The alluvial aquifer is unconfined and in direct contact with surface water so that it can be affected by surface discharge.

As for the Loire River (Grosbois et al., 2000), there are three distinct periods in the Allier river's annual hydrological

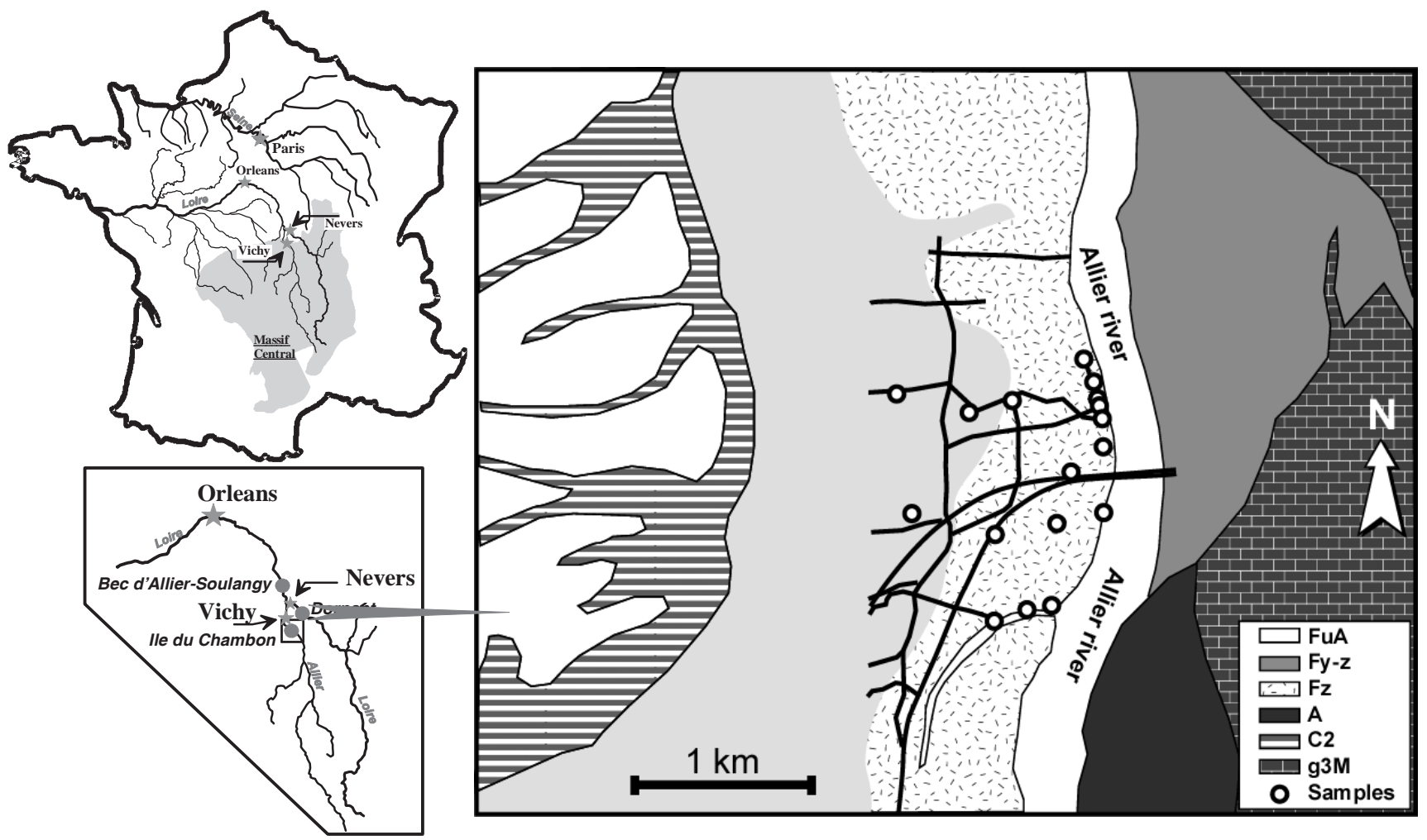

Fig. 1. General location map of the Ile du Chambon catchment in the Allier River watershed. Geological framework and location of the sampling points. The sedimentary deposits include g3M (Oligocene limestones and marls), C2 (g3M-derived colluvium), A (sandy colluvium), $F z, F y-z$, FuA (alluvial deposits, sometimes marly calcareous and made of sands, gravels and pebbles derived from granite, undifferentiated volcanic and metamorphic rocks). 
cycle: (a) low flow, around $30 \mathrm{~m}^{3} \mathrm{~s}^{-1}$, during two or three warm months in the summer, (b) high flow in winter, usually from January to February, with short periods of flooding during which flow reaches $160 \mathrm{~m}^{3} \mathrm{~s}^{-1}$, and (c) lower high flow in the spring during melting of snow in the Massif Central.

The basin's alluvial plain is used primarily for agriculture, (maize and cereal) and animal husbandry. Some of the water data might, therefore, reflect the effects of agriculture in addition to primary geologic effects. The underlying Ile du Chambon riverbank aquifer constitutes a valuable water reservoir that is tapped for drinking water and agriculture.

In addition to chemical and isotopic surveys of the groundwater, piezometric levels were measured during low and high water stages to determine flow patterns. Groundwater levels were also measured each month by the BDQE (Bureau de la Qualité de l'Eau-Conseil Général de l'Allier: Water Quality Survey-Allier General Council). Hydraulic gradient maps show two preferential flow paths towards topographic lows (Fig. 2a and 2b). The first flows down the hillside towards the Allier River, while the second flows almost parallel to the river and probably corresponding

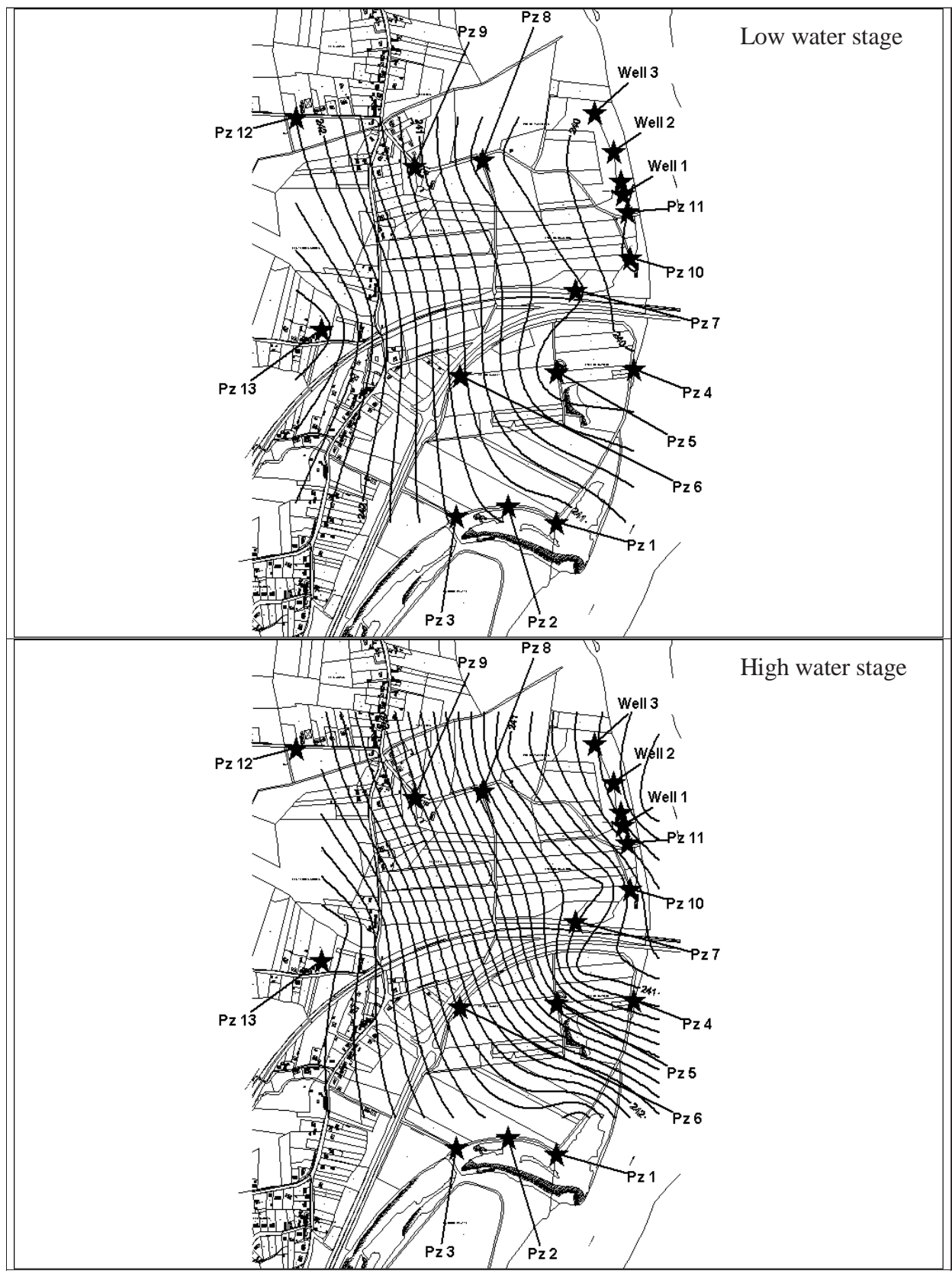

Fig. 2. Maps of the hydraulic gradient in the alluvial aquifer during low (a) and high (b) water stages in the Ile du Chambon catchment. Water levels are expressed in $m$ vs. NGF (French levelling survey). 
Table 1. $\mathrm{pH}$, total dissolved solids $\left(\mathrm{mg} \mathrm{l}^{-1}\right)$, major $\left(\mathrm{mg} \mathrm{l}^{-1}\right)$ and trace $\left(\mu \mathrm{g} \mathrm{l}^{-1}\right)$ element concentrations, ${ }^{87} \mathrm{Sr} /{ }^{86} \mathrm{Sr}$ ratios, of the dissolved load in surface- and groundwaters from the Ile du Chambon catchment during low (a) and high (b) water stages.

\begin{tabular}{llllllllllllll}
\hline Samples & \multirow{2}{*}{$\mathrm{pH}$} & $\mathrm{TDS}$ & $\mathrm{Ca}$ & $\mathrm{Mg}$ & $\mathrm{Na}$ & $\mathrm{Km}$ & $\mathrm{Cl}$ & $\mathrm{NO}_{3}$ & $\mathrm{SO}_{4}$ & $\mathrm{HCO}_{3}$ & $\mathrm{Sr}$ & ${ }^{87} \mathrm{Sr} /{ }^{86} \mathrm{Sr}$ \\
& & $m g l^{-1}$ & $m g l^{-1}$ & $m g l^{-1}$ & $m g l^{-1}$ & $m g l^{-1}$ & $m g l^{-1}$ & $m g l^{-1}$ & $m g l^{-1}$ & $\mu g l^{-1}$
\end{tabular}

(a) Low water stage

$\begin{array}{lllllllllllll}\text { Well 1 } & 6.62 & 518 & 733 & 17 & 24 & 7 & 19 & 37 & 33 & 308 & 505 & 0.71175 \\ \text { Well 2 } & 6.73 & 497 & 70 & 19 & 16 & 8 & 19 & 42 & 30 & 293 & 540 & 0.71099 \\ \text { Well 3 } & 6.74 & 498 & 71 & 19 & 16 & 8 & 19 & 43 & 30 & 293 & 532 & 0.71092 \\ \text { Well 4 } & 6.64 & 505 & 71 & 17 & 20 & 7 & 18 & 45 & 30 & 296 & 518 & 0.71161 \\ \text { PZ1 } & 7.2 & 436 & 57 & 12 & 27 & 8 & 29 & <0.2 & 2 & 301 & 382 & 0.71168 \\ \text { PZ2 } & 7.17 & 405 & 51 & 10 & 30 & 9 & 30 & <0.2 & 1 & 274 & 319 & 0.71168 \\ \text { PZ3 } & 7.13 & 538 & 74 & 15 & 32 & 9 & 32 & 8 & 29 & 338 & 438 & 0.71165 \\ \text { PZ4 } & 7.18 & 463 & 64 & 16 & 22 & 6 & 22 & 26 & 29 & 277 & 473 & 0.71164 \\ \text { PZ5 } & \text { Nd } & 560 & 79 & 18 & 26 & 6 & 23 & 34 & 42 & 331 & 514 & 0.71174 \\ \text { PZ6 } & 6.79 & 594 & 76 & 19 & 33 & 9 & 22 & 15 & 30 & 389 & 520 & 0.71163 \\ \text { PZ7 } & 6.80 & 570 & 77 & 18 & 28 & 11 & 23 & 21 & 30 & 363 & 622 & 0.71178 \\ \text { PZ8 } & 6.91 & 500 & 72 & 19 & 17 & 5 & 20 & 35 & 24 & 307 & 564 & 0.71033 \\ \text { PZ10 } & 6.89 & 591 & 82 & 18 & 28 & 7 & 23 & 30 & 35 & 367 & 606 & 0.71180 \\ \text { PZ12 } & 7.25 & 517 & 66 & 21 & 19 & 15 & 19 & 34 & 24 & 319 & 497 & 0.70892 \\ \text { PZ13 } & 6.98 & 570 & 83 & 22 & 20 & 3 & 28 & 53 & 28 & 332 & 581 & 0.71110 \\ \text { Allier } & & & & & & & & & & & 170 \\ \text { upstream } & 8.79 & 187 & 22 & 7 & 19 & 4 & 20 & 4 & 15 & 96 & 178 & 0.71133 \\ \text { downstream } & 8.80 & 197 & 22 & 7 & 21 & 5 & 21 & 4 & 15 & 102 & 181 & 0.71133\end{array}$

(b) High water stage

\begin{tabular}{lllllllllllll} 
Well 1 & 7.04 & 533 & 80 & 18 & 25 & 7 & 18 & 31 & 30 & 323 & 480 & 0.71180 \\
Well 2 & 7.01 & 461 & 71 & 18 & 16 & 8 & 16 & 40 & 26 & 267 & 450 & 0.71113 \\
Well 3 & 7.21 & 486 & 73 & 19 & 16 & 8 & 17 & 36 & 25 & 292 & 460 & 0.71082 \\
Well 4 & 6.93 & 487 & 78 & 18 & 22 & 8 & 16 & 27 & 28 & 289 & 480 & 0.71165 \\
PZ1 & 7.66 & 366 & 54 & 11 & 21 & 7 & 21 & $<0.2$ & 24 & 228 & 280 & 0.71170 \\
PZ2 & 7.6 & 363 & 56 & 11 & 18 & 7 & 20 & $<0.2$ & 27 & 224 & 270 & 0.71172 \\
PZ3 & 7.55 & 534 & 84 & 17 & 28 & 8 & 32 & $<0.2$ & 51 & 313 & 370 & 0.71168 \\
PZ4 & 7.08 & 559 & 86 & 21 & 23 & 7 & 28 & 53 & 38 & 304 & 500 & 0.71162 \\
PZ5 & 7.17 & 511 & 82 & 19 & 26 & 7 & 26 & 40 & 34 & 277 & 420 & 0.71173 \\
PZ6 & 7.03 & 613 & 90 & 21 & 39 & 10 & 26 & 7 & 36 & 383 & 500 & 0.71163 \\
PZ7 & 6.85 & 626 & 94 & 20 & 29 & 12 & 23 & 23 & 32 & 393 & 610 & 0.71179 \\
PZ8 & 6.84 & 472 & 77 & 20 & 20 & 6 & 24 & 24 & 26 & 276 & 510 & 0.71036 \\
PZ10 & 6.91 & 593 & 91 & 20 & 28 & 8 & 24 & 40 & 39 & 344 & 560 & 0.71179 \\
PZ11 & 6.86 & 579 & 86 & 20 & 26 & 11 & 21 & 25 & 33 & 357 & 550 & 0.71179 \\
PZ12 & 7.14 & 538 & 74 & 23 & 19 & 17 & 20 & 0.2 & 25 & 360 & 450 & 0.70871 \\
PZ13 & 7.00 & 578 & 93 & 24 & 21 & 4 & 21 & 21 & 25 & 370 & 550 & 0.71111 \\
Allier & & & & & & & & & & & 85 \\
upstream & 8.05 & 164 & 21 & 6 & 13 & 4 & 16 & 2 & 12 & 88 & 140 & 0.71127 \\
downstream & 8.04 & 160 & 21 & 6 & 13 & 4 & 17 & 0.2 & 12 & 87 & 140 & 0.71126 \\
Well near PZ10 & 7.35 & 572 & 93 & 19 & 26 & 9 & 23 & 19 & 40 & 342 & 520 & 0.71151 \\
\hline
\end{tabular}

to a palaeo-channel. Furthermore, these maps show identical groundwater flow patterns in the Ile du Chambon catchment during low and high water stages. The only difference is the lower piezometric levels during low water stages.

\section{Sampling and analytical methods}

River and groundwater samples in the alluvial area were collected twice, during a low water stage in July 2002 and during a high water stage in February 2003. Groundwater was collected in piezometers, purged prior to sampling by 
pumping three times their volume. Wells were sampled directly as they are continuously used for water supply. River water was collected according to Grosbois et al. (2001) and Négrel et al. (2003). Master variables were measured in situ. Electrical conductivity and water temperature were measured using a WTW 330i microprocessor conductivity meter standardised to $20^{\circ} \mathrm{C}$. $\mathrm{pH}$ was measured on site using a WTW 330i pH-meter previously calibrated using standard buffers.

The chemical composition of the water samples was determined by atomic absorption spectrometry ( $\mathrm{Ca}, \mathrm{Na}, \mathrm{K}$, $\mathrm{Mg}$, accuracy 5-10\%), ion chromatography $\left(\mathrm{Cl}, \mathrm{SO}_{4}, \mathrm{NO}_{3}\right.$, accuracy 5-10\%) and inductively coupled plasma mass spectrometry ( $\mathrm{Sr}$ and $\mathrm{Rb}$ trace elements, accuracy 5\%). Chemical separation of $\mathrm{Sr}$ was done with an ion-exchange column ( $\mathrm{Sr}-\mathrm{Spec}$ ), with total blank $<0.5 \mathrm{ng}$ for the entire chemical procedure. After chemical separation, one-fifth of each sample was loaded onto a tungsten filament and analysed with a Finnigan MAT 262 multiple collector mass spectrometer. The ${ }^{87} \mathrm{Sr} /{ }^{86} \mathrm{Sr}$ ratios were normalised to a ${ }^{86} \mathrm{Sr} /$ ${ }^{88} \mathrm{Sr}$ ratio of 0.1194 . An average internal precision of \pm 10 . $10^{-6}(2 \sigma)$ was obtained during this study. The reproducibility of ${ }^{87} \mathrm{Sr} /{ }^{86} \mathrm{Sr}$ ratio measurements was tested by duplicate analyses of the NBS 987 standard and the mean value was $0.710233 \pm 31.10^{-6}(2 \sigma, \mathrm{n}=9)$. The anthropogenic sources (chemical fertilisers, manure and sewage) were characterised by measuring $\mathrm{Sr}$ isotopes. Manure samples were obtained by lixiviation according to the procedures given by Widory et al. (2004).

The charge balance (Table 1) defined as $\left\{100 *\left(\Sigma^{+}-\Sigma^{-}\right) /\right.$ $\left.\left(\Sigma^{+}+\Sigma^{-}\right)\right\}$represents the fractional difference between the total cations $\Sigma^{+}$and total anions $\Sigma^{-}$(Edmond et al., 1995). The major cations measured $\mathrm{Na}^{+}, \mathrm{Ca}^{2+}, \mathrm{Mg}^{2+}, \mathrm{K}^{+}$should balance the charge of the major anions $\mathrm{Cl}^{-}, \mathrm{SO}_{4}{ }^{2-}, \mathrm{NO}_{3}^{-}$, $\mathrm{HCO}_{3}^{-}$(e.g. Huh et al., 1998). In this study, most of the water samples showed a charge imbalance mainly in favour of an excess negative charge, but some inversely in favour of a deficit positive charge. The electro neutrality in the range of $\pm 5 \%$ falls within the range of analytical uncertainties.

\section{Results}

\section{CHEMICAL COMPOSITION OF GROUND- AND} RIVER WATERS

Table 1 shows the chemical and strontium isotope composition of the dissolved load for the low- and high water surveys, respectively, in the surface- and groundwater. Total dissolved solids (TDS, Table 1) in the groundwater vary from 405 to $594 \mathrm{mg} \mathrm{l}^{-1}$ during the dry period and 363 to $626 \mathrm{mg} \mathrm{l}^{-1}$ during the wet period, in agreement with Négrel et al. (2003). In the wells, TDS varies by only $\pm 10 \%$ during the two periods and recorded values are similar. However, in the piezometers, TDS values vary greatly during each period from one piezometer to another but are in the same range for the two periods. The lowest values were measured in PZ2 during both periods, while the highest values were measured in PZ6 during the dry period and in PZ7 during the wet period. There was no detectable variation in TDS in river water samples collected up- and downstream between the dry (187-197 $\mathrm{mg} \mathrm{l}^{-1}$ ) and wet (160-164 $\mathrm{mg} \mathrm{l}^{-1}$ ) periods. The Allier river values are the same as those given in Négrel et al. (1997a, 2003).

Chloride content ranges from 16 to $21 \mathrm{mg} \mathrm{l}^{-1}$ in the river water and from 16 to $32 \mathrm{mg} \mathrm{l}^{-1}$ in the groundwater (Fig. 3) and does not vary significantly with time. $\mathrm{Cl}$ ions do not participate in weathering reactions since local lithologies contain no evaporite. The $\mathrm{Cl}$ ions in ground- and surface water, therefore, come from sea salt (Meybeck, 1983, 1986) and human activity, and behave conservatively throughout the hydrological cycle. Although they have been used as an atmospheric-input reference in many unpolluted hydrosystems (Meybeck, 1983; Négrel, 1999), they can also come from a variety of human activities and are found in domestic sewage, fertilisers, de-icing salts, etc. Figure 3 shows data collected from the Allier river $50 \mathrm{~km}$ upstream (Négrel et al., 1997a) during low water stage throughout a complete hydrological cycle, and from the Allier river $70 \mathrm{~km}$ downstream (Négrel et al., 2003). Rainfall input is also plotted and represents the mean weighted concentration of 13 samples of rainwater $(970 \mathrm{~mm})$ collected over a oneyear period in the Massif Central (Négrel and Roy, 1998), with one sample representing all of the rainwater that fell during a one-month period, multiplied by the concentration factor of four.

Dissolved ion and $\mathrm{Cl}$ concentration covariations reveal three geochemical behaviour patterns. (a) $\mathrm{Na}, \mathrm{K}$ and $\mathrm{SO}_{4}$ in river water and groundwater samples display a strong trend from low towards higher concentrations when plotted against $\mathrm{Cl}$ in Fig. 3. Like $\mathrm{Cl}, \mathrm{Na}$ varies greatly and values lie above the seawater-dilution line (sw), indicating that $\mathrm{Na}$ content increases through water-rock interactions related to silicate weathering. The mean weighted rain end-member plots on the seawater-dilution line indicating that both $\mathrm{Cl}$ and $\mathrm{Na}$ in rains over the Massif Central come from sea salt as demonstrated by Négrel and Roy (1998). Compared to river water, groundwater is enriched in $\mathrm{SO}_{4}$ except at two points with very low $\mathrm{SO}_{4}$ concentrations. $\mathrm{K}$ concentrations also display the same behaviour (Fig. 3), some points being only $\mathrm{K}$-enriched (no correlated $\mathrm{Cl}$ enrichment). High sulphate and potassium contents, above those of the Allier 

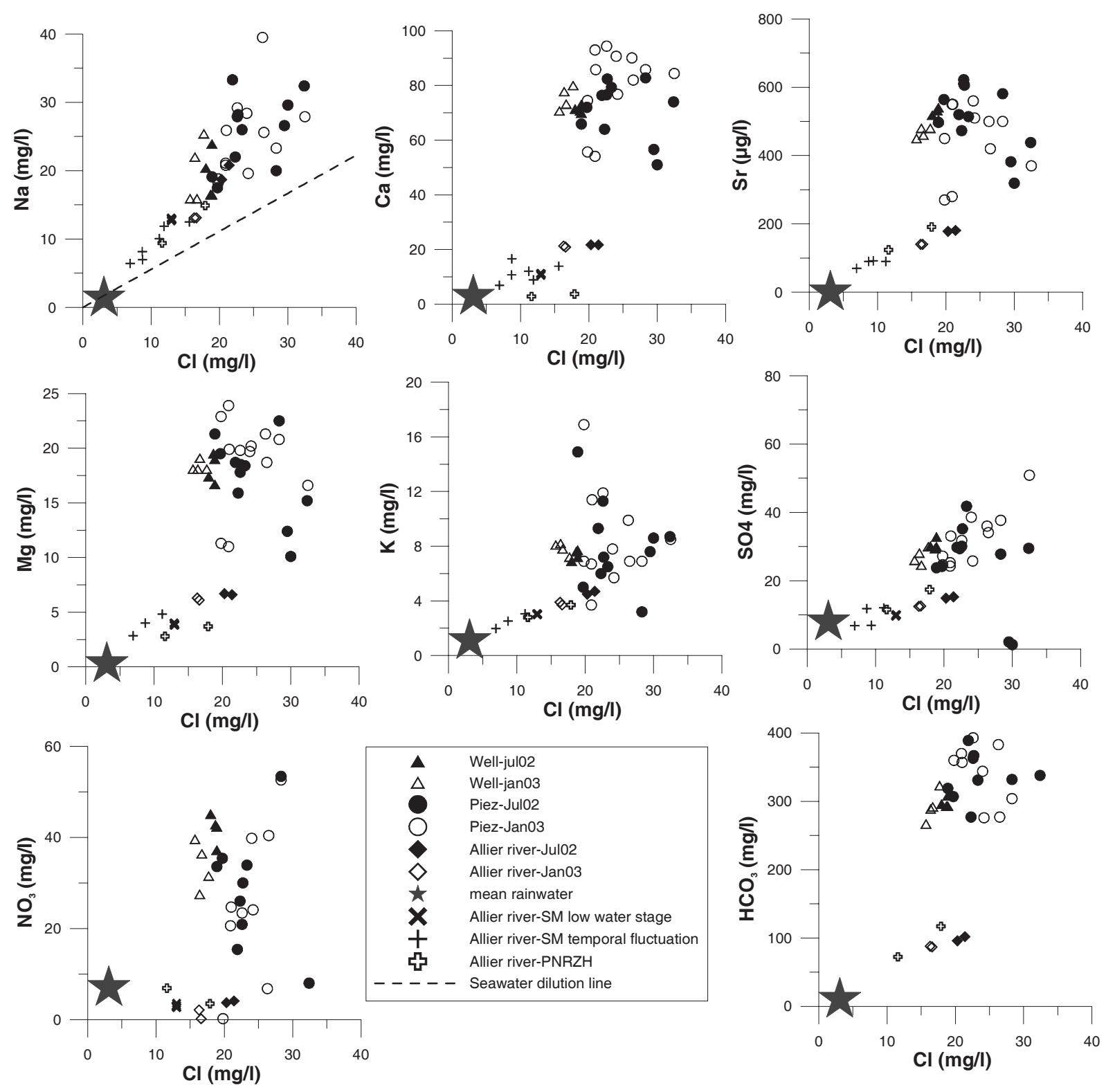

Fig. 3. $\mathrm{Na}, \mathrm{Ca}, \mathrm{Sr}, \mathrm{Mg}, \mathrm{K}, \mathrm{SO}_{4}, \mathrm{NO}_{3}$ and $\mathrm{HCO}_{3}$ vs. Cl contents (in $\mathrm{mg} \mathrm{l}^{-1}$ ) for the groundwater collected in the Ile du Chambon catchment and Allier river water during low and high water stages. The mean rainwater value is from Négrel and Roy (1998).

river, must have an anthropic origin as stated by Widory et al. (in press). (b) For nitrate, most of the groundwater defines a vertical trend with large variations (Fig. 4). This would reflect agricultural practices, possibly the application of manure and fertilisers and, in places, sewage effluent. Three points display $\mathrm{NO}_{3}$ contents below $10 \mathrm{mg} \mathrm{l}^{-1}$ with a $\mathrm{Cl}$ content in the range of $20-35 \mathrm{mg} \mathrm{l}^{-1}$. Denitrification can also cause $\mathrm{NO}_{3}$ concentrations to vary (Widory et al., in press). (c) The third pattern applies to most species $(\mathrm{Ca}$, $\mathrm{Mg}, \mathrm{Sr}, \mathrm{HCO}_{3}$ ) with concentrations being largely enriched in groundwaters and plotting above the trend defined in the Allier river water (Fig. 3). Such enrichments, especially in
$\mathrm{Ca}$ and $\mathrm{HCO}_{3}$ might reflect carbonate dissolution since the Oligocene bedrock contains marly limestone. The carbonate system in waters was studied by comparing calcium and bicarbonate calculated in $\mu$ eq $1^{-1}$. However, most of the data points fall below the $\mathrm{Ca}=\mathrm{HCO}_{3}$ equivalent line, favouring the anion influence and inferring that another cation is necessary to reach the balance. $\mathrm{Ca}+\mathrm{Mg}$ was therefore plotted as a function of $\mathrm{HCO}_{3}$ (Fig. 4). Points are better scattered around the 1:1 line from rainwater, river water towards shallow groundwater in the Oligocene aquifer in the Limagne area (Négrel et al., 1997b).

The PHREEQC geochemical code (Parkhurst and Appelo, 


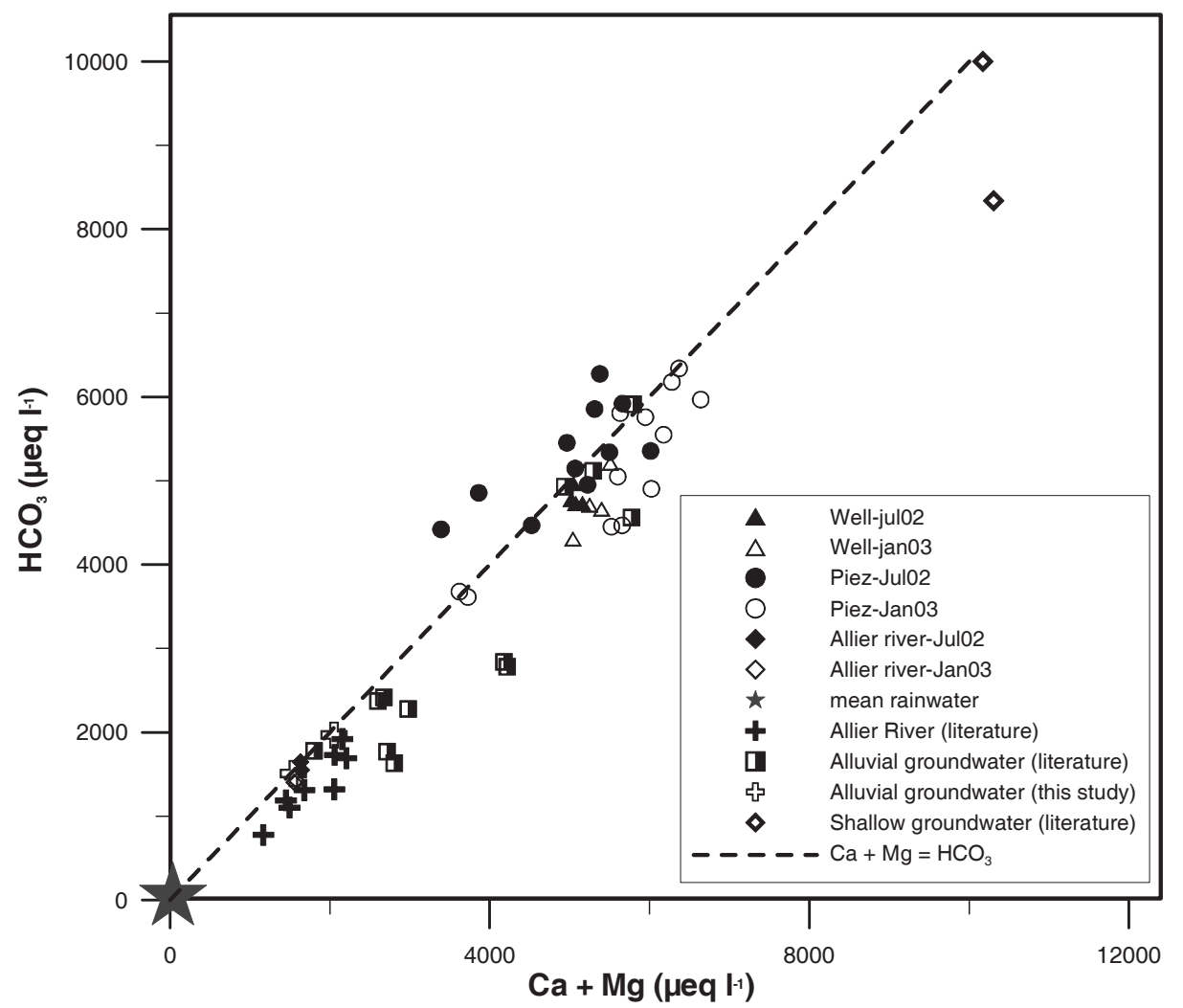

Fig. 4. $\mathrm{Ca}+\mathrm{Mg}$ vs. $\mathrm{HCO}_{3}$ (in $\mu$ eq. $l^{-1}$ ) for groundwater collected in the Ile du Chambon catchment and Allier river water during low and high water stages The dashed line corresponds to the 1:1 line. Black crosses correspond to Allier river water data from the literature (Négrel et al., 1997a, b, 2003). Open diamonds correspond to shallow groundwater from the Oligocene aquifer in the Limagne (Négrel et al., 1997b). Mean rainwater is from Négrel and Roy (1998). Mid-black squares correspond to alluvial groundwater along the Loire-Allier river valleys (Négrel at al., 2003).

1999) was used to compute the saturation indices (SI). The values obtained for the relevant solid phases were used as criteria for determining the solids likely to precipitate under the measured physico-chemical conditions. A SI of zero indicates equilibrium, a positive value indicates oversaturation and a negative value undersaturation, with respect to the solid phases. Groundwater saturation indices during both the low or high water stages with respect to calcite are always undersaturated $(\mathrm{SI}=-0.4)$ to near equilibrium ( $\mathrm{SI}=-0.06)$. Groundwater saturation indices are always undersaturated with respect to aragonite, (SI = -0.5 ) and dolomite (SI $=-1.2,-0.4)$. For surface water collected during the low water stage, PHREEQC gives a behaviour different from groundwater since the saturation indices are oversaturated with respect to calcite $(\mathrm{SI}=0.70)$, aragonite $(\mathrm{SI}=0.57)$ and dolomite $(\mathrm{SI}=1.30)$. The SI values for carbonate species agree with precipitation of an authigenic component as revealed in the Loire River (Négrel et al., 2000, 2003; Grosbois et al., 2000, 2001). During the high water stage, the river water is clearly undersaturated in carbonate species, as also shown by Négrel et al. (2003).

\section{STRONTIUM AND ITS ISOTOPES}

The strontium contents in the various groundwater samples vary by a factor of two, from 319 to $622 \mu \mathrm{g} \mathrm{l}^{-1}$, during the low water stage. A similar range is observed during the high water stage (270 to $610 \mu \mathrm{g}^{-1}$ ). This range in Sr contents in groundwater agrees with previous work on groundwater sampled from alluvial aquifers in the Loire catchment (Négrel et al., 2003). Sr contents in surface water are lower, around $180 \mu \mathrm{g} \mathrm{l}^{-1}$ during the low water stage and $140 \mu \mathrm{g} \mathrm{l^{-1 }}$ during the high water stage. Values do not vary between upstream and downstream. Sr contents in surface water are strongly correlated to $\mathrm{Cl}$ (Fig. 3). This indicates a common origin and implies that $\mathrm{Sr}$ content is influenced by agricultural practises by spreading of fertilisers (Négrel and Deschamps (1996) and Négrel (1999). The large increase in $\mathrm{Sr}$ contents in groundwater without any similar increase in $\mathrm{Cl}$ contents reflects a $\mathrm{Sr}$ input associated with carbonate dissolution. This is also evidenced by the good linear relationships between $\mathrm{Sr}$ and the carbonate system: $\mathrm{Sr} v s$. $\mathrm{Ca}\left(\mathrm{r}^{2}=0.81\right), \mathrm{Sr} v$ s. $\mathrm{Mg}\left(\mathrm{r}^{2}=0.82\right), \mathrm{Sr} v$. $\mathrm{HCO}_{3}\left(\mathrm{r}^{2}=0.83\right)$.

The ${ }^{87} \mathrm{Sr} /{ }^{86} \mathrm{Sr}$ ratios range from 0.70892 (PZ12) to 0.71180 
Table 2. Sr concentrations $\left(\mathrm{mg} \mathrm{g}^{-1}\right),{ }^{87} \mathrm{Sr} /{ }^{86} \mathrm{Sr}$ ratios of three fertilisers (urea, chloride and $\mathrm{N}-\mathrm{NO}_{3}$ ), three animal manures and three sewage effluents.

\begin{tabular}{lcl}
\hline & $S r\left(\mathrm{mg} \mathrm{g}^{-1}\right)$ & ${ }^{87} \mathrm{Sr} /{ }^{86} \mathrm{Sr}$ \\
\hline urea & 4 & 0.70911 \\
chloride & 86 & 0.71157 \\
$\mathrm{~N}^{-N_{3}}$ & 2 & 0.70791 \\
& & \\
manure A & 305 & 0.70978 \\
manure B & 203 & 0.7089 \\
manure C & 153 & 0.71035 \\
& & \\
sewage 1 & 190 & 0.7109 \\
sewage 2 & 260 & 0.71092 \\
sewage 3 & 430 & 0.71061 \\
\hline
\end{tabular}

(PZ10) during the low water stage, and from 0.70871 (PZ12) to 0.71179 (PZ07) during the high water stage, in agreement with Négrel et al. (2003). The ${ }^{87} \mathrm{Sr} /{ }^{86} \mathrm{Sr}$ ratios of the Allier river water are the same up- and downstream, during both the low water stage $(0.71133)$ and the high water stage (0.71126-0.71127), and are in total agreement with Négrel et al. (2003) in another area of the Loire-Allier valleys' alluvial aquifer system (Loire valley at Dornant site and Allier valley at the Soulangy site, $70 \mathrm{~km}$ downstream the Ile du Chambon), and in partial agreement with Négrel et al. (1997a) for the Allier river water collected $50 \mathrm{~km}$ upstream throughout a hydrological cycle.

Anthropogenic sources ${ }^{87} \mathrm{Sr} /{ }^{86} \mathrm{Sr}$ (Table 2) vary from 0.70791 for ammonium nitrate $\left(\mathrm{N}-\mathrm{NO}_{3}\right)$ fertiliser, which has a very low $\mathrm{Sr}$ content $\left(2 \mu \mathrm{g} \mathrm{l}^{-1}\right)$, to 0.71155 for chloride fertiliser, which has a higher $\mathrm{Sr}$ content $\left(86 \mu \mathrm{g} \mathrm{l^{-1 }}\right)$. These fall within the general range of fertilisers as defined by Négrel (1999), Widory et al. (2004) and Négrel and Pauwels (2004) in France as well as that of Vitòria et al. (2004) in Spain and references therein. Animal manure has Sr isotope ratios of 0.70890 to 0.71035 and a Sr content ranging from 150 to $305 \mu \mathrm{g} \mathrm{l}^{-1}$. Sewage effluent has ${ }^{87} \mathrm{Sr} /{ }^{86} \mathrm{Sr}$ ratios of 0.71061 to 0.71092 and variable $\mathrm{Sr}$ contents $\left(190-430 \mu \mathrm{g}^{-1}\right)$.

\section{Discussion}

\section{STRONTIUM SOURCES IN GROUNDWATER}

The $\mathrm{Sr}$ isotopic composition of groundwater from various alluvial aquifers can be compared to constrain the groundwater/surface water systems (Bullen et al., 1996; Eikenberg et al., 2001; Ojiambo et al., 2003). This is based on the fact that ${ }^{87} \mathrm{Sr} /{ }^{86} \mathrm{Sr}$ ratios vary with $\mathrm{Rb} / \mathrm{Sr}$ ratios and the age of the material and, since natural processes do not fractionate $\mathrm{Sr}$ isotopes, the measured differences in ${ }^{87} \mathrm{Sr} /$ ${ }^{86} \mathrm{Sr}$ ratios are the result of mixing of $\mathrm{Sr}$ from different sources with different isotopic compositions (Faure, 1986). In this study, since the range of $\mathrm{Sr}$ isotopic compositions (Table 1) is greater than the analytical errors for the procedure $\left(2 \cdot 10^{-5}\right),{ }^{87} \mathrm{Sr} /{ }^{86} \mathrm{Sr}$ variations within the hydrosystem can provide information concerning the sources of $\mathrm{Sr}$ and the different mixing processes involved (Fisher and Stueber, 1976; Bain et al., 1998). The sources of Sr that might control the ${ }^{87} \mathrm{Sr} /{ }^{86} \mathrm{Sr}$ ratio can be constrained by the relationships between the $\mathrm{Sr}$ isotopic composition and concentration ratios (Négrel, 1999; Roy et al., 1999; Hogan et al., 2000), which produce straight lines (Faure, 1986). Figure 5 illustrates the relationship in a ${ }^{87} \mathrm{Sr} /{ }^{86} \mathrm{Sr} v s$. $1 / \mathrm{Sr}$ graph. The solute concentration and $\mathrm{Sr}$ isotopic ratio for groundwater vary slightly between low and high water stages, reflecting groundwater mixing over at least one hydrological cycle. The capacitive effect commonly observed in many aquifers could buffer variations in the different inputs.

Figure 5 involves at least a three end-members mixing: (a) the Allier River, represented by high ${ }^{87} \mathrm{Sr} /{ }^{86} \mathrm{Sr}$ and high $1 / \mathrm{Sr}$ ratios, (b) groundwater characterised by high ${ }^{87} \mathrm{Sr} /{ }^{86} \mathrm{Sr}$ and low 1/Sr ratios (e.g. groundwater from PZ7 and 10), and (c) groundwater characterised by low ${ }^{87} \mathrm{Sr} /{ }^{86} \mathrm{Sr}$ and high 1/Sr ratios (e.g. groundwater from PZ12). These could be related to different water-rock interactions in the catchment. The binary mixing trend connecting the river water to PZ7 and 10 would reflect the infiltration of surface water into

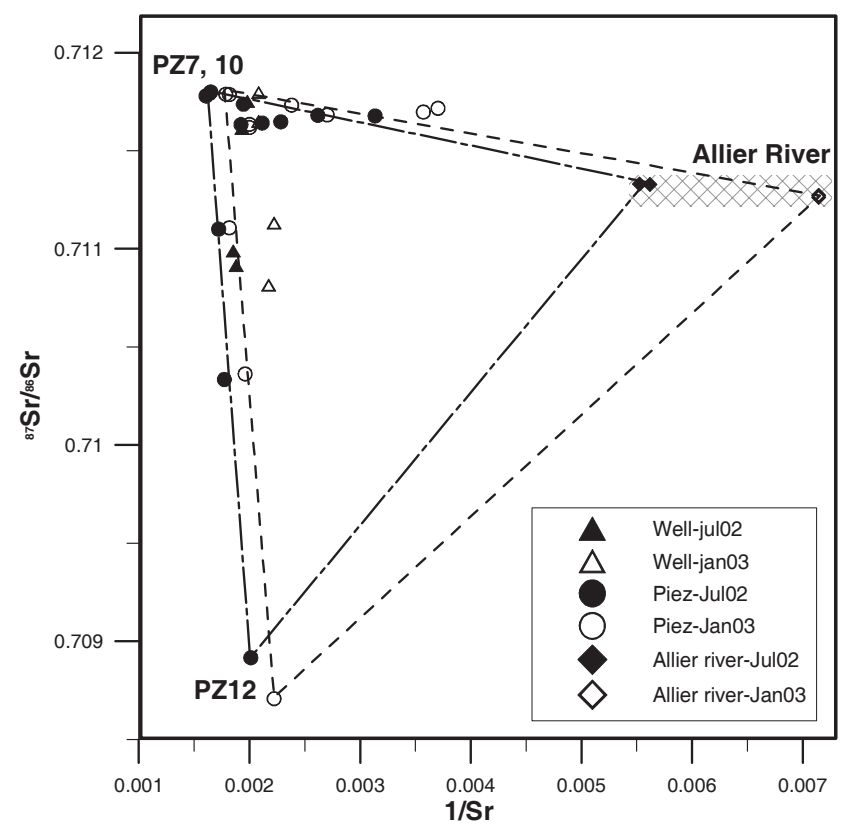

Fig. $5 .{ }^{87} \mathrm{Sr} /{ }^{86} \mathrm{Sr}$ vs. 1/Sr for groundwater collected in the Ile du Chambon catchment and Allier river water during low and high water stages. 
the alluvial formations. Along this mixing trend, the variations in $\mathrm{Sr}$ content are greater than those of the ${ }^{87} \mathrm{Sr} /$ ${ }^{86} \mathrm{Sr}$ ratio, reflecting the input of lesser $\mathrm{Sr}$-concentrated surface water. The binary mixing trend connecting the river water to groundwater from PZ12, shows only small variations in the $\mathrm{Sr}$ content and greater variations in ${ }^{87} \mathrm{Sr} /$ ${ }^{86} \mathrm{Sr}$. Since the major ions and $\mathrm{Sr}$ chemistry are evidence for the role of carbonate dissolution in these waters, both PZ7 and 10 and PZ12 should correspond to the weathering of Oligocene calcareous-marl. However, their ${ }^{87} \mathrm{Sr}{ }^{86} \mathrm{Sr}$ are very different, low for PZ12 and much higher for PZ7 and 10. In the Ile du Chambon catchment, part of the bedrock, overlaid by fluviatile deposits and drained by the Allier river, consists of Oligocene deposits. Elsewhere in France during the Upper Oligocene mixed marine, fresh-water and brackish beds are found (Sissingh, 2001). In the Limagne graben system there are more than $3000 \mathrm{~m}$ of sands, arkoses, clays and freshwater limestones. All lacustrine deposits are of fresh-water, brackish, marine and terrestrial origin (Dadet et al., 1979; 1980; Bodergat et al., 1999; Briot et al., 2001). The deposition of carbonate in a pure, classical lacustrine environment yields $\mathrm{Sr}$ isotopic ratios reflecting that of water with a typical continental value $(>0.710)$. In the southern part of the Limagne bordering the Massif Central basement and drained by the Allier River some $70 \mathrm{~km}$ south of the Ile du Chambon catchment, Bodergat et al. (1999) and Briot et al. (2001) found high ${ }^{87} \mathrm{Sr} /{ }^{86} \mathrm{Sr}$ ratios in the Oligocene lacustrine carbonate with values ranging from 0.712 to 0.715 . The highest values are believed to be the result of granite-gneiss erosion (present day ${ }^{87} \mathrm{Sr} /{ }^{86} \mathrm{Sr}$ in granitegneiss-derived waters in the Massif Central are $>0.714$; Négrel, 1999). The lower ${ }^{87} \mathrm{Sr} /{ }^{86} \mathrm{Sr}$ in the Oligocene deposits is interpreted as the result of sudden marine inundations (Bodergat et al., 1999; Briot et al., 2001) with waters having a ${ }^{87} \mathrm{Sr}{ }^{86} \mathrm{Sr}$ ratio of around $0.70785-0.70825$ (Miller et al., 1988). In contrast with the southern Limagne, Oligocene lacustrine deposits located $100 \mathrm{~km}$ north of the Ile du Chambon catchment give $\mathrm{Sr}$ isotopic ratios of 0.70809 to 0.70823 and $\mathrm{Sr}$ concentrations of 27 to $50 \mathrm{ppm}$ (Casanova et al., 2001), in agreement with the marine signal during the Oligocene (marine carbonate $=0.70785-0.70825$; Miller et al., 1988). These values reflect the marine signal recorded in the Oligocene deposits just north of the site while typical 'continental' signatures are observed just south of the site. This seems to indicate that the end-member with the lowest isotopic signature, represented by PZ12, would reflect the weathering of Oligocene deposits with the typical 'marine' signature while the other, represented by PZ7 and 10, would reflect the weathering of Oligocene deposits with the typical 'continental' signature. This signature is derived primarily from weathering of granite and volcanic rocks from the
Massif Central (Bodergat et al., 1999 and Briot et al., 2001). The groundwater in PZ12, located on the hillside, would correspond to the weathering of the sedimentary deposits without any transportation (the basement) while the groundwater in PZ7 and 10 would correspond to sediments transported from the southern part of the Limagne and included in the alluvial Quaternary deposits (Dadet et al., 1979; Delance et al., 1988) with the associated 'continental' signature.

The three end-members involved in the mixing processes are the Allier River, the radiogenic end-member represented by PZ7 and 10, which corresponds to the weathering of Oligocene deposits in the alluvial plain, and the lowradiogenic end-member represented by $\mathrm{PZ12}$, which corresponds to the weathering of Oligocene deposits in the bedrock. Figure 5 shows clearly that some samples plot directly on the mixing line connecting the Allier River to PZ7 and 10. This mixing line includes PZ1, 2, 3, 5, and well 1 at the low water stage and PZ1, 2, 3, 4, 6, and well 1 at the high water stage. PZ13, 8 and well 3 (during the low water stage only) plot along the mixing line connecting PZ7 and 10 to PZ12. All other points lie within the triangle whose apexes are the Allier River, PZ7 and 10, and PZ12. Along the mixing line connecting the Allier River and PZ12, few points are coherent with the maps of the hydraulic gradient (Fig. 2); this precludes any link between these two endmembers.

Agricultural practices can influence Sr isotopes, as demonstrated by Négrel and Deschamps (1996); Négrel (1999) and Böhlke and Horan (2000). Anthropogenic disturbance through agricultural activity causes an input of $\mathrm{Sr}$, the extent of which depends on the contents of fertilisers and carbonate additives (3-1500 $\mu \mathrm{g} \mathrm{g}^{-1}$ ) and manure (cattle, hogs and poultry). Other studies, however, have shown that $\mathrm{Sr}$ isotopes are dependent on bedrock geology alone and are not influenced by land use, even in agricultural zones (Semhi et al., 2000; Douglas et al., 2002). This enables Sr isotopes to be used to distinguish among catchments draining different bedrock types. The possible influence of agricultural practices must, however, be studied and in the Ile du Chambon catchment, they include the growing of maize and cereals and animal husbandry. Sr isotopes were measured in chemical fertilisers, manure (cattle) and sewage sludge. Fertilisers are clearly distinguishable from the ground- and surface water as they have much lower $\mathrm{Sr}$ contents $(1 / \mathrm{Sr}$ of $0.012-0.23$, whereas the lowest $1 / \mathrm{Sr}$ ratio in the Allier River is less than 0.007). Manure has roughly overlapping ${ }^{87} \mathrm{Sr} r{ }^{86} \mathrm{Sr}$ ratios, while those of sewage sludge clearly overlap in the mixing diagram but do not represent a pure end-member; therefore, they cannot be considered as water resulting from the mixing processes between the 
three end-members defined above. Hence, the $\mathrm{Sr}$ isotopes are considered as representative of the drainage of the different bedrock types and a tracer of the mixing processes.

\section{MIXING RELATIONSHIPS AND HYDROLOGICAL RAMIFICATIONS}

Most Sr isotope studies of rivers and lakes have shown that variations in ${ }^{87} \mathrm{Sr} /{ }^{86} \mathrm{Sr}$ and $\mathrm{Sr}$ contents are caused primarily by mixing of waters of various origins that have different ${ }^{87} \mathrm{Sr} /{ }^{86} \mathrm{Sr}$ and $\mathrm{Sr}$ contents (Lent et al., 1997; Katz et al., 1998; Hogan et al., 2000; Semhi et al., 2000). Figure 5 shows that most of the groundwater in the Ile du Chambon catchment plots along two mixing lines. Each binary mixture can be expressed isotopically as follows (Faure, 1986):

$$
\begin{aligned}
{ }^{87} \mathrm{Sr} /{ }^{86} \mathrm{Sr} \mathrm{m} \times[\mathrm{Sr}]_{\mathrm{m}}= & \left({ }^{87} \mathrm{Sr} /{ }^{86} \mathrm{Sr}_{1} \times[\mathrm{Sr}]_{1}\right)+(1-) \\
& \left({ }^{87} \mathrm{Sr} /{ }^{86} \mathrm{Sr}_{2} \times[\mathrm{Sr}]_{2}\right)
\end{aligned}
$$

where ${ }^{87} \mathrm{Sr} /{ }^{86} \mathrm{Sr} \mathrm{m}$ is the measured isotopic ratio $[\mathrm{Sr}] \mathrm{m}$ in the mixture and ${ }^{87} \mathrm{Sr} /{ }^{86} \mathrm{Sr} 1$ and ${ }^{87} \mathrm{Sr} /{ }^{86} \mathrm{Sr} 2$ represent the isotopic ratios of the first $[\mathrm{Sr}] 1$ and second $[\mathrm{Sr}] 2$ endmember, respectively. The mixing parameter derived from Eqn. (1) represents the proportions of the two components in the mixture $(0<f<1)$. Assuming that the end members are Allier river water, the low radiogenic component represented by PZ12 (hillslope) and the high radiogenic component represented by PZ7 and 10 (alluvial groundwater) can be calculated for each sample on the mixing trend as well as for those lying within the triangle (Petelet et al., 1998). The proportions of each end-member in each piezometer and well are given in Fig. 6a and $6 \mathrm{~b}$ for low and high water stages, respectively.

In agreement with the hydraulic gradients shown in Figs. $2 \mathrm{a}$ and $2 \mathrm{~b}, 20$ to $70 \%$ of the groundwater in PZ1 to 6 comes from the Allier River during either the low or high water stage. The proportions of surface water are higher during the high water stage in PZ1, 3 and 5 while those of PZ2, 4 and 6 are roughly similar during high and low water stages. This would reflect preferential flow in the alluvial deposits with some areas being more stagnant (e.g. PZ2, 4, 6). The flow down the hillside has a slight impact (around 2\%) on PZ6 during the low water stage and on PZ4 and 6 (around $5 \%$ ) during the high water stage. This is in agreement with the proportion of hillside water in PZ13 (around 30\% during the two water stages) and with the hydraulic gradients. Most of the water in PZ4, 5 and 6 comes from the alluvial aquifer sensu stricto (s.s.), i.e. with the 'continental' Oligocene signature. PZ8, located on the hillside, has proportions of both alluvial aquifer s.s. and slope water (around 50\%) during both low and high water stages. While the wells are
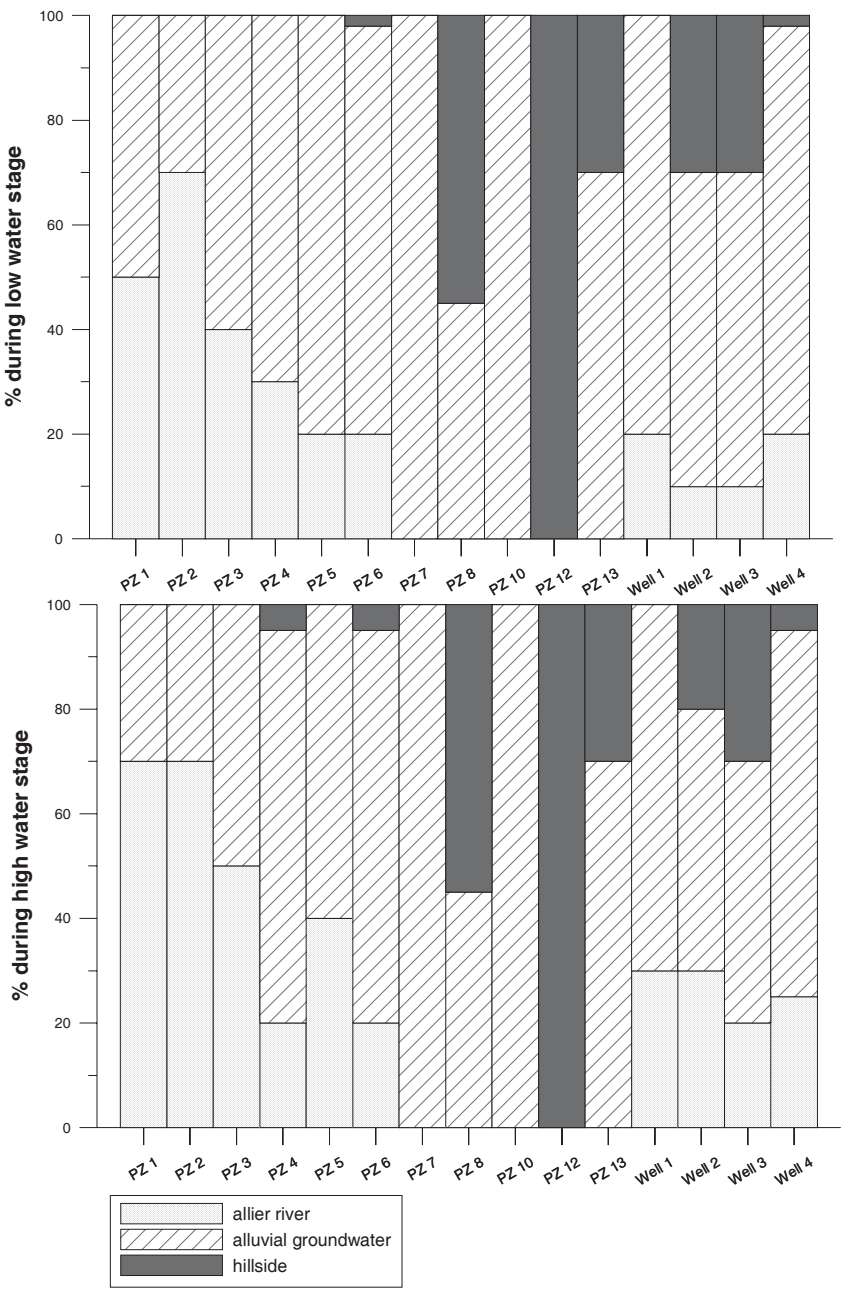

Fig. 6a, b. Proportions of the different end-members (the Allier river, the low radiogenic component represented by the PZ12

corresponding to the weathering of Oligocene bedrock, and the high radiogenic component represented by the PZ7 and 10,

corresponding to the weathering of Oligocene deposits in the alluvial plain), in each piezometer and well for the low (a) and high (b) water stages.

influenced by all three end-members, the hydraulic gradients indicate that the influence of river water would be nil. The influence of the Allier River in the drinking water wells cannot easily be related to flow in the alluvial deposits as the hydraulic gradients preclude it. The most credible hypothesis is that there is bank infiltration of river water as claimed by Ray et al. (2002) and Schubert (2002). The results also indicate a large influence of alluvial aquifer s.s. water (50 to $80 \%$ ), whereas that of slope water is very low in wells 1 and 4 ( 0 to 5\%) and much higher in wells 2 and 3 (20 to $30 \%$ ). This implies that there are two sub-flows; one is located in the far north of the zone, affecting wells 2 and 3 with a large discharge of water from the hillside, while another, $100 \mathrm{~m}$ to the south, is more marked by the alluvial 
aquifer s.s. This indicates that there are numerous preferential flow paths in the area, which result in the different proportions of the various end-members, even within the short distances between some of the piezometers and wells.

\section{HYDROLOGICAL IMPLICATIONS FOR ALLUVIAL AQUIFERS}

Alluvial aquifers are crucial because they supply large quantities of water to drinking water wells. They can be affected by surface activity and can act as vectors of pollution between sources and valuable surface water resources. Knowledge of the fundamental characteristics of alluvial aquifers within the greater hydrological continuum should include a broader multidimensional analyse coupled with hydraulic characterisation, spatial variability (quantity, quality) and effects of land use, by application of crossdisciplinary points of view.

The description of the different groundwater systems in another area of the Loire-Allier valleys' alluvial aquifer system, the 'Bourbonnais' and Quaternary alluvial deposits (Négrel et al., 2003), illustrates the difficulties involved in characterising riverbank alluvial aquifers, especially, if several different aquifer levels within the alluvium have been demonstrated. By characterising three different sites in the Loire-Allier valleys within the Bourbonnais-Quaternary alluvium, the $\mathrm{Sr}$ isotopes in both surface and groundwater can be synthesised. Figure 7 gives an overview of the ${ }^{87} \mathrm{Sr} /$ ${ }^{86} \mathrm{Sr} v s .1 / \mathrm{Sr}$ ratios in the surface- and groundwater in the Ile du Chambon catchment and at the Dornant and Soulangy sites (Négrel et al., 2003), Allier river water collected $50 \mathrm{~km}$ upstream throughout a hydrological cycle (Négrel et al., 1997a), shallow groundwater emerging in lacustrine deposits from southern Limagne near the Allier river (Négrel et al., 1997b), groundwater from drinking water wells in the Loire valley - one near Nevers (AEP1) and another near Soulangy (AEP2) (Fig. 1).

Surface water in the Allier and Loire rivers defines a field with decreasing ${ }^{87} \mathrm{Sr} /{ }^{86} \mathrm{Sr}$ associated with decreasing $1 / \mathrm{Sr}$ ratios reflecting the fluctuation of the $\mathrm{Sr}$ systematic depending on the rocks drained (granite or basalt). This results in variable ${ }^{87} \mathrm{Sr} /{ }^{86} \mathrm{Sr}$ and $\mathrm{Sr}$ contents. The lowest values correspond to more drainage through basalt during rainy events (Négrel and Deschamps, 1996; Négrel et al., 1997a) while higher ${ }^{87} \mathrm{Sr} /{ }^{86} \mathrm{Sr}$ values correspond to more drainage through granite (Négrel, 1999).

Comparing the Sr isotopes in alluvial groundwater in Fig. 7, it is noted that:

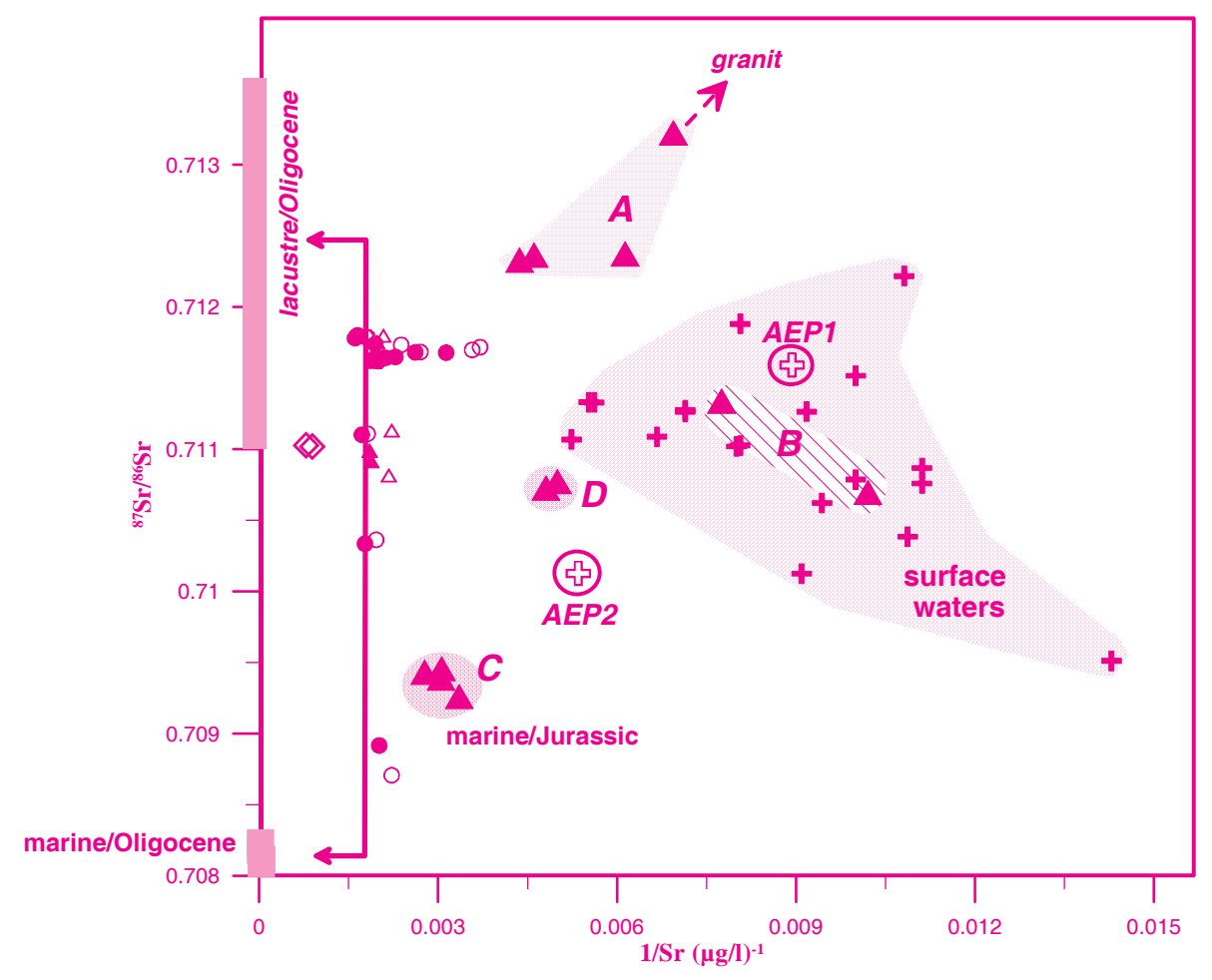

Fig. 7. Global relationship between the ${ }^{87} \mathrm{Sr} /{ }^{86} \mathrm{Sr}$ and $1 / \mathrm{Sr}$ ratios in alluvial groundwater in the Allier and Loire river valleys (Négrel et al., 1997b; 2003; this study) and in river water (Négrel et al., 1997a; 2003). Symbols are the same as in Figure 4 and fields A to D are defined in the text. 
- The groundwater forming field A has the highest ${ }^{87} \mathrm{Sr} /$ ${ }^{86} \mathrm{Sr}$ and defines a trend towards high ${ }^{87} \mathrm{Sr} /{ }^{86} \mathrm{Sr}$-low $\mathrm{Sr}$ content. This groundwater displays ${ }^{87} \mathrm{Sr} /{ }^{86} \mathrm{Sr}$ typical of water having interacted with granite (Négrel, 1999; Petelet-Giraud et al., 2003) and would be consistent with the presence and weathering of detrital products in the alluvium resulting from erosion of the granite region of the Massif Central. The difference between the ${ }^{87} \mathrm{Sr} /{ }^{86} \mathrm{Sr}$ of this groundwater and those of Loire river water, which are always lower, argues in favour of a local signature.

- The high ${ }^{87} \mathrm{Sr} /{ }^{86} \mathrm{Sr}$ corresponding to the samples from the Ile du Chambon catchment might be related to the influence of the weathering of Oligocene lacustrine deposits on the water signature.

- The lowest ${ }^{87} \mathrm{Sr} /{ }^{86} \mathrm{Sr}$ corresponding to groundwater forming field C (deep alluvial aquifer in the Soulangy site, Négrel et al., 2003) and groundwater from the Ile du Chambon catchment might be related to the influence of the weathering of the Jurassic or Oligocene marine deposits on the water signature as discussed above.

- There is no evidence of variations in $\mathrm{Sr}$ content of groundwater draining the Oligocene deposits. They differ only in their ${ }^{87} \mathrm{Sr} r{ }^{86} \mathrm{Sr}$. Two samples of shallow groundwater from the south Limagne, near the Allier river, plot with an intermediate signature because they are influenced by the drainage of the lacustrine part of the Oligocene deposits (Négrel et al., 1997b, Briot et al., 2001). They confirm the range in waters draining these deposits since they are located in the typical lacustrine part of the Limagne.

- The groundwater forming field B (shallow alluvial aquifer in the Dornant site, Négrel et al., 2003) plots within the field of surface water in Fig. 7 and can, therefore, be considered to be fed by input from rivers. The groundwater forming field D (shallow alluvial aquifer in the Soulangy site, Négrel et al., 2003) plots slightly outside the surface water field but can, nevertheless, be considered to be fed largely by rivers. A possible influence of Jurassic marine deposits on the water signature cannot, however, be ruled out.

- Groundwaters from drinking water wells in the Loire valley plot separately. AEP1, near the town of Nevers, plots within the surface water field and, therefore, can be considered to be fed by the river, while AEP2, near the Soulangy site plots between fields $\mathrm{C}$ and $\mathrm{D}$ (all from the same site) and illustrates the variability of the groundwater signature.

This figure highlights, clearly, the variations in the Sr isotope signature in the alluvial groundwater in the Loire/Allier river valleys and shows the potential ability of this isotopic tool to determine groundwater mixing in alluvial environments for water resource management.

\section{Conclusions}

This study focused on strontium isotope data and major ions from shallow groundwater and river water in the alluvial valley of the Loire and Allier rivers, France. This work is part of the increasing use of geochemical tools such as $\mathrm{Sr}$ isotopes the better to understand the structure and functioning of alluvial aquifers. Water chemistry revealed large variations in major-element contents. Plotting $v s . \mathrm{Cl}$ chemical elements reflects water rock interactions (e.g., silicate weathering for $\mathrm{Na}$, carbonate dissolution for $\mathrm{Ca}, \mathrm{Mg}$, $\mathrm{HCO}_{3}$, and $\mathrm{Sr}$ since the bedrock contains marly limestones and agricultural input from farming and fertilising and, in places, the spreading of sewage effluent for $\mathrm{NO}_{3}, \mathrm{~K}, \mathrm{SO}_{4}$ ), although some water samples are clearly unpolluted. The $\mathrm{NO}_{3}$ shows variations but none for $\mathrm{Cl}$, which could be due to denitrification processes.

The range in $\mathrm{Sr}$ contents in groundwater agrees with previous work on groundwater from alluvial aquifers in the Loire catchment. Values of ${ }^{87} \mathrm{Sr} /{ }^{86} \mathrm{Sr}$ range from 0.70892 to 0.71180 during low and high water stages, also in agreement with other studies. However, the large increase in Sr contents in groundwater without any correlated increase in $\mathrm{Cl}$ contents indicates an input of $\mathrm{Sr}$ linked to carbonate dissolution. This is corroborated by good linear relationships between $\mathrm{Sr}$ and the carbonate system: $\mathrm{Sr} v s . \mathrm{Ca}\left(\mathrm{r}^{2}=0.81\right)$, $\mathrm{Sr} v s . \mathrm{Mg}\left(\mathrm{r}^{2}=0.82\right), \mathrm{Sr} v s . \mathrm{HCO}_{3}\left(\mathrm{r}^{2}=0.83\right)$.

$\mathrm{A}^{87} \mathrm{Sr} /{ }^{86} \mathrm{Sr} v .1 / \mathrm{Sr}$ diagram shows that groundwater results a mixing involving at least three geochemical signatures: (a) the Allier River and two signatures that could be related to different water rock interactions in the catchment, (b) a radiogenic end-member corresponding to the weathering of Oligocene deposits in the alluvial plain, and (c) a lowradiogenic end-member corresponding to the weathering of Oligocene deposits in the bedrock. This reflects the heterogeneity in the Oligocene deposits in the Loire-Allier valleys from a marine towards a lacustrine end-member. Of two sub-flows identified isotopically (in agreement with the maps of hydraulic gradient), one is in the extreme north of the zone with a large discharge of water from the hillside while the other, around $100 \mathrm{~m}$ to the south, is more characteristic of the alluvial aquifer s.s. This reflects, and confirms, the existence of several preferential flows in this area, giving different proportions of the different endmembers, even within the small distances separating the piezometers and wells.

The characterisation of three different sites in the Loire- 
Allier valleys within the Bourbonnais-Quaternary alluvium synthesises the $\mathrm{Sr}$ isotopes budget in both surface- and groundwater. The groundwater data lie between extreme end-members represented by the surface water in the Allier and Loire rivers; Jurassic and/or Oligocene marine deposits whose weathering resulted in low ${ }^{87} \mathrm{Sr} /{ }^{86} \mathrm{Sr}$ ratios; Oligocene lacustrine deposits whose weathering resulted in high ${ }^{87} \mathrm{Sr} /$ ${ }^{86} \mathrm{Sr}$ ratios; some groundwater has ${ }^{87} \mathrm{Sr} /{ }^{86} \mathrm{Sr}$ typical of water having interacted with granite, associated with the presence and weathering of detrital products in the alluvium, resulting from the erosion of granite in the Massif Central.

\section{Acknowledgements}

This work was funded by SIAEP Vendat-St Rémy en RollatCharmeil and BRGM Research Division. Chemical and isotopic analyses were performed in the BRGM Geochemistry Laboratory, France. The work benefited from the collaboration of C. Guerrot (BRGM Mass-Spectrometer team) who provided the strontium isotope analyses. The authors also thank the BRGM Translation Service for improving the English. The authors warmly thank Th. Prade, M. Goulefert (SIAEP Vendat-S ${ }^{t}$ Rémy en Rollat-Charmeil), B. Mann and M. Tournaire (BDQE, General Council Allier) and S. Grau (Gaudriot SA) for their collaboration and the site accessibility.

\section{References}

Adams, S., Titus, R., Pietersen, K., Tredoux, G. and Harris, C., 2001. Hydrochemical characteristics of aquifers near Sutherland in the Wester Karoo, South Africa. J. Hydrol., 241, 91-103.

Bain, D.C., Midwood, A.J. and Miller, J.D., 1998. Strontium isotope ratios in streams and the effect of flow rate in relation to weathering in catchments. Catena, 32, 143-151.

Bodergat, A.M., Briot, D., Hugueney, M., Poidevin, J.L., Picot, L., Giraud, F., Berger, J.P., Levy, A. and Poignant, A., 1999. Incursions marines dans l'environnement lacustre du rift oligocène de Limagne (Massif Central, France) : apport des organismes halophiles et des isotopes du strontium, datation par les mammifères. Bull. Soc. Géol. Fr., 170, 499-511.

Böhlke, J.K.and Horan, M., 2000. Strontium isotope geochemistry of groundwaters and streams affected by agriculture, Locust Grove, MD. Appl. Geochem., 15, 599-609.

BRGM. 1983. Précipitations efficaces moyennes annuelles en France. Map of France at 1: 1 500,000 scale. Explanatory Notes. BRGM, Orléans, 83 SGN 003 EAU. 40pp.

Briot, D., Poidevin, J.L. and Hugueney, M., 2001. Apports de l'étude isotopique $\mathrm{Sr}$ et $\mathrm{Nd}$ des sédiments cénozoïques de Limagne à la compréhension du fonctionnement du rift du Massif Central Français. Bull. Soc. Géol. Fr.Au:, 172, 17-24.

Bullen, T.D., Krabbenhoft, D.P. and Kendall, C., 1996. Kinetic and mineralogic controls on the evolution of groundwater chemistry and ${ }^{87} \mathrm{Sr} /{ }^{86} \mathrm{Sr}$ in a sandy silicate aquifer, northern Wisconsin, USA. Geochim. Cosmochim. Acta, 60, 1807-1821.
Casanova, J., Négrel, Ph. and Giot, D., 2001. Isotope signatures associated with ferricrusts, calcretes and palustrine deposits from the Early Eocene Bourges Formation, Central France. $4^{\text {th }}$ International Symposium on Applied Isotope Geochemistry, June 2001, Menlo Park, California, USA. 97-99.

Dadet, P., Clozier, L., Giot, D., Fleury, R., Belkessa, R., Batard, F., Carroué, J.P., Jeambrun, M., Châteauneuf, J.J., Farjanel, G. and Tourenq, J., 1979. Geological Map of France at 1:50,000 scale, Vichy Sheet. Explanatory Notes. BRGM, Orléans. 51pp.

Dadet, P., Jeambrun, M., Van Tiet, L., Clozier, L., Fleury, R., Giot, D., Gagnière, G., Batard, F. and Carroué, J.P., 1980. Geological Map of France at 1:50,000 scale, Maringues Sheet. Explanatory Notes. BRGM, Orléans, 54pp.

Delance, J.H., Lablanche, G., Clozier, L., Debrand-Passard, S., Gros, Y., Cornet, J., Martins, Cl., Vautrelle, Ch. and Gratier, M., 1988. Geological Map of France at 1:50,000 scale, Nevers Sheet. Explanatory Notes. BRGM, Orléans, 55pp.

Douglas, T.A., Chamberlain, C.P. and Blum, J.D., 2002. Land use and geologic controls on the major elemental and isotopic $\left(\delta^{15} \mathrm{~N}\right.$ and ${ }^{87} \mathrm{Sr} /{ }^{86} \mathrm{Sr}$ ) geochemistry of the Connecticut River watershed, USA. Chem. Geol., 189, 19-34.

Edmond, J.M., Palmer, M.R., Measures, C.I., Grant, B. and Stallard, R.F., 1995. The fluvial geochemistry and denudation rate of the Guayana shield in Venezuela. Geochim. Cosmochim. Acta, 59, 3301-3325.

Eikenberg, J., Tricca, A., Vezzu, G., Stille, P., Bajo, S. and Ruethi, M., 2001. ${ }^{228} \mathrm{Ra} /{ }^{226} \mathrm{Ra} /,{ }^{228} \mathrm{Ra} /{ }^{224} \mathrm{Ra}$ and ${ }^{87} \mathrm{Sr} /{ }^{86} \mathrm{Sr}$ isotope relationships for determining interactions between ground and river water in the upper Rhine valley. J. Environ. Radioact., 54, 133-162.

Faure, G., 1986. Principles of Isotope Geology. Wiley, Chichester, UK. 589pp.

Fisher, R.S. and Stueber, A.M., 1976. Strontium isotopes in selected streams within the Susquehanna River Basin. Water Resour. Res., 12, 1061-1068.

Giot, D., Gentilhomme, P., Bouiller, R., Clozier, L., Fleury, R., Belkessa, R., Rey, R., Châteauneuf, J.J. and Tourenq, J., 1976. Geological Map of France at 1:50,000 scale, Maringues Sheet. Explanatory Notes. BRGM, Orléans. 32pp.

Grosbois, C., Négrel, Ph., Fouillac, C. and Grimaud, D., 2000. Chemical and isotopic characterization of the dissolved load of the Loire river. Chem. Geol., 170, 179-201.

Grosbois, C., Négrel, Ph., Fouillac, C. and Grimaud, D., 2001. An overview of dissolved and suspended matter fluxes in the Loire river basin: natural and anthropogenic inputs. Aquat. Geochem., 7, 81-105.

Guo, H. and Wang, Y., 2004. Hydrogeochemical processes in shallow quaternary aquifers from the northern part of the Datong Basin, Chine. Appl. Geochem. 19, 19-27.

Hogan, J.F., Blum, J.D., Siegel, D.I. and Glaser, P.H., 2000. ${ }^{87} \mathrm{Sr} /$ ${ }^{86} \mathrm{Sr}$ as a tracer of groundwater discharge and precipitation recharge in the Glacial Lake Agassiz, Peatlands, northern Minnesota. Water Resour. Res., 36, 3701-3710.

Huh, Y., Tsoi, M.Y., Zaitsev, A. and Edmond, J.M., 1998. The fluvial geochemistry of the rivers of Eastern Siberia: I. Tributaries of the Lena River draining the sedimentary platform of the Siberian craton. Geochim. Cosmochim. Acta, 62, 16571676.

Katz, B.G., Catches, J.S., Bullen, T.D. and Michel, R.L., 1998. Changes in the isotopic and chemical composition of ground water resulting from a recharge pulse from a sinking stream. $J$. Hydrol., 211, 178-207.

Lent, R.M., Gaudette, H.E. and Lyons, W.B., 1997. Strontium isotopic geochemistry of the Devils Lake drainage system, North Dakota: A preliminary study and potential paleoclimatic implications. J. Paleolimnol., 17, 147-154. 
Meybeck, M., 1983. Atmospheric inputs and river transport of dissolved substances. IAHS Publ. no. 141, 173-192.

Meybeck, M., 1986. Composition chimique des ruisseaux non pollués en France. Sci. Géol. Bull., 39, 3-77.

Miller, K.G., Feigenson, M.D., Kent, D.V. and Olsson, R.K., 1988. Upper Eocene to Oligocene isotope $\left({ }^{87} \mathrm{Sr} /{ }^{86} \mathrm{Sr}, \delta^{18} \mathrm{O}, \delta^{13} \mathrm{C}\right)$ standard section, deep sea drilling project site 522 . Paleoceanog., 3, 223-233.

Négrel, Ph., 1999, Geochemical study of a granitic area - The Margeride Mountains, France: chemical element behavior and ${ }^{87} \mathrm{Sr}{ }^{86} \mathrm{Sr}$ constraints. Aquat. Geochem., 5, 125-165.

Négrel, Ph, and Deschamps, P. ,1996, Natural and anthropogenic budgets of a small watershed in the Massif Central (France): Chemical and strontium isotopic characterization in water and sediments. Aquat. Geochem., 2, 1-27.

Négrel, Ph. and Pauwels, H., 2004. Interaction between different groundwaters in Brittany catchments (France): characterizing multiple sources through strontium- and sulphur isotope tracing. Water Air Soil Pollut., 151, 261-285.

Négrel, Ph. and Roy, S., 1998. Rain chemistry in the Massif Central (France). A strontium isotopic and major elements study. Appl. Geochem., 13, 941-952.

Négrel, Ph, Fouillac, C. and Brach, M., 1997a. Occurrence of mineral water springs in the stream channel of the Allier River (Massif Central, France): chemical and $\mathrm{Sr}$ isotope constraints. J. Hydrol., 203, 143-153.

Négrel, Ph., Fouillac, C. and Brach, M., 1997b. Variations spatiotemporelles de la composition chimique et des rapports ${ }^{87} \mathrm{Sr} /$ ${ }^{86} \mathrm{Sr}$ des eaux minérales de la Limagne d'Allier. C.R. Acad. Sci., 324, 119-124.

Négrel, Ph., Grosbois, C. and Kloppmann, W., 2000. The labile fraction of suspended matter in the Loire river (France): multielement chemistry and isotopic ( $\mathrm{Rb}-\mathrm{Sr}$ and $\mathrm{C}-\mathrm{O})$ systematics. Chem. Geol., 166, 271-285.

Négrel, Ph., Petelet-Giraud, E., Barbier, J. and Gauthier, E., 2003. Surface water-groundwater interactions in an alluvial plain: Chemical and isotopic systematics. J. Hydrol., 277, 248-277.

Ojiambo, S.B., Lyons, W.B., Welch, K.A., Poreda, R.J. and Johannesson, K.H., 2003. Strontium isotopes and rare earth elements as tracers of groundwater-lake water interactions, Lake Naivasha, Kenya. Appl. Geochem., 18, 1789-1805.
Parkhurst, D.L. and Appelo, C.A.J., 1999. User's guide to PHREEQC (version 2)-A computer program for speciation, batch-reaction, one-dimensional transport, and inverse geochemical calculations: U.S. Geological Survey WaterResources Investigations Report 99-4259, 312pp.

Petelet-Giraud, E., Luck, J.M., Ben Othman, D., Négrel, Ph. and Aquilina, L., 1998. Geochemistry and water dynamics on a medium sized watershed: the Herault, S France. Chem. Geol., 150, 63-83.

Petelet-Giraud, E., Négrel, Ph. and Casanova, J., 2003. Variability of ${ }^{87} \mathrm{Sr} /{ }^{86} \mathrm{Sr}$ in water draining granite revealed after a double correction for atmospheric and anthropogenic inputs. Hydrolog. Sci. J., 48, 729-742.

Ray, C., Soong, T.W., Lian, Y.Q. and Roadcap, G.S., 2002. Effect of flood-induced chemical load on filtrate quality at bank filtration sites. J. Hydrol., 266, 235-258.

Roy, S., Gaillardet, J. and Allègre, C.J., 1999. Geochemistry of dissolved and suspended loads of the Seine river, France: anthropogenic impact, carbonate and silicate weathering. Geochim. Cosmochim. Acta, 63, 1277-1292.

Schubert, J., 2002. Hydraulic aspects of riverbank filtration - field studies. J. Hydrol., 266, 145-161.

Semhi, K., Clauer, N. and Probst, J.L., 2000. Strontium isotope compositions of river waters as records of lithology-dependent mass transfers: the Garonne river and its tributaries (SW France). Chem. Geol, 168, 173-193.

Sikdar, P.K., Sarkar, S.S. and Palchoudhury, S., 2001. Geochemical evolution of groundwater in the quaternary aquifer of Calcutta and Howrah, India. J. Asian Earth Sci., 19, 579-594.

Sissingh, W., 2001. Tectonostratigraphy of the west Alpine foreland: correlation of Tertiary sedimentary sequences, changes in eustatic sea-level and stress regimes. Tectonophys., 333, 361400.

Vitòria, L., Otero, N., Soler, A. and Canals, A., 2004. Fertilizer Characterization: Isotopic Data (N, S, O, C, and Sr). Environ. Sci. Technol., 38, 3254-3262.

Widory, D., Kloppmann, W., Chery, L., Bonnin, J. and Rochdi, H., 2004. Nitrates in groundwater : an isotopic multi-tracer approach. J. Contam. Hydrol., 72, 165-188.

Widory, D., Petelet-Giraud, E. and Négrel, Ph., (in press). Tracing nitrate sources in groundwater by coupled nitrogen and boron isotopes: A synthesis. Environ. Sci. Technol. 